\title{
10. PETROLOGY AND CHEMISTRY OF BASALTS FROM DSDP LEG 46
}

\author{
Floyd N. Hodges, Dept. of Geology, Furman University, Greenville, South Carolina
}

\begin{abstract}
DSDP Leg 46 cored 205.5 meters into basement at Hole 396B $\left(22^{\circ} 59.14^{\prime} \mathrm{N}, 43^{\circ} 30.90^{\prime} \mathrm{W}\right)$. Basal sediments at the site are middle Miocene ( $\sim 13$ m.y.B.P.) in age. Basement at the site consists principally of pillows of normal low-K oceanic tholeiite. One relatively thick ( 9-m) cooling unit was encountered. The hole bottomed in 90 meters of coarse clastic material of basaltic composition. Pillow lavas at the site consist of an upper sparsely phyric (olivine and plagioclase $<1 \%$ ) and a lower strongly phyric (olivine and plagioclase) unit. The groundmass crystallization sequence in both units is olivine, plagioclase, clinopyroxene, and titanomagnetite. Cr-rich spinel is a minor component in many of the basalts. Major element chemistry indicates that the pillow units can be divided into several similar but unrelated magma batches. The clastic unit, containing a large proportion of fresh, angular fragments of basaltic glass, is apparently a tectonic debris or talus unit, probably associated with a fault scarp. The clastic unit is capped by a zeolite-cemented basaltic breccia unit that apparently sealed the clastic unit off from direct sea water circulation.
\end{abstract}

\section{INTRODUCTION}

Hole 396B of Leg 46 of Glomar Challenger (located at $22^{\circ} 59.14^{\prime} \mathrm{N}, 43^{\circ} 30.90^{\prime} \mathrm{W}$, approximately $160 \mathrm{~km}$ east of the Mid-Atlantic Ridge) penetrated 205.5 meters into basement. Basement at the site, which consists principally of basaltic pillows and fragmental material of basaltic composition, was encountered beneath 151 meters of nannofossil ooze. The basal part of the sedimentary section is middle Miocene ( $\sim 13$ m.y. B.P.) in age (Site Report, this volume).

The basement rocks recovered at Hole 396B can be divided into three major units: a sparsely olivine and plagioclase phyric upper basalt unit (Core 4 through Sample $15-5,100 \mathrm{~cm} ; 151$ to $342 \mathrm{~m}$ sub-bottom), an olivine-plagioclase phyric basalt unit (Cores 15 through 22; 342 to $315 \mathrm{~m}$ ), and a sequence consisting of basaltic clastic material with either interlayered pillow sequences or zones of coarser basaltic clastic debris (Cores 23 through 33, 315 to $405.5 \mathrm{~m}$ ).

On the basis of shipboard XRF analyses, the samples were divided into chemical units A, B, and C, corresponding to the three major lithologic units. The top two units were further sub-divided (i.e., A1, A2, A3, B1, B2) on the basis of minor but apparently consistent chemical variation, particularly in $\mathrm{Ti}$ (Site Report, this volume).

\section{PETROLOGY}

The upper basaltic unit at Hole 396B was divided into two lithologic units. Unit 1 (Samples $4-1,12 \mathrm{~cm}$ to $13-2$, $20 \mathrm{~cm}$ ) and Unit 2 consist of similar basaltic pillows and were separated on the basis of a $20-\mathrm{cm}$ interval of well-lithified limestone (Sample 13-2, 1-20 cm). Lithologic Unit 3 consists of a single cooling unit ( $\sim 9 \mathrm{~m}$ thick) in Core 15 , and is described in detail elsewhere (Kirkpatrick and Hodges, this volume).

Basalts from lithologic Units 1 and 2 are very sparsely phyric, containing less than 1 per cent of olivine and plagioclase phenocrysts in roughly equal proportions. Plagioclase phenocrysts are typically subhedral to anhedral, many of the phenocrysts and glomerocrysts having distinctly rounded outlines. Many of the plagioclase phenocrysts contain melt inclusions, either glass or devitrified glass, aligned parallel to the composition planes of polysynthetic twins. Olivine phenocryst and microphenocrysts are typically subhedral and skeletal and in a few cases occur intergrown with plagioclase. Larger olivine phenocrysts tend to be rounded and embayed and exhibit kink bands in a few cases. Alteration of olivine to iddingsite is common throughout.

Margins of the pillows are glassy, with microlites of olivine and plagioclase. In several cases, the plagioclase microlites are partly segregated and are aligned parallel to the pillow margins, apparently a result of flow differentiation during emplacement. Vesicles within the glassy pillow margins are commonly decorated with tiny $(\sim 1 \mu \mathrm{m})$ blebs of sulfide. Inward from the margins, the pillows normally pass through well-developed variolitic and spherulitic zones, typically within the length of a thin section. Interiors of the pillows are generally intersertal. Skeletal groundmass olivine is common throughout. Skeletal plagioclase is present through the pillow interiors and clinopyroxene and titanomagnetite appear only in the coarser portions of pillow interiors. The groundmass crystallization sequence appears to be olivine, plagioclase, 
clinopyroxene, and titanomagnetite. The textural development of the pillows is treated in detail by Kirkpatrick (this volume).

Alteration is ubiquitous throughout the samples. Glass in the pillow margins is commonly partly replaced by palagonite, particularly along fractures, and residual glass within pillow interiors is replaced by smectite. Calcite is minor but widespread in the pillow interiors and commonly occurs in fracture fillings veins with zeolite. Zeolites occur both as vesicle filling material and in veins with calcite. In veins, the zeolites invariably grow outward from the vein walls in radial aggregates and calcite fills the central portion of the vein. Vug-like voids within the variolitic zone of Sample 4-1, 118-122 cm are lined with radial aggregates of length-slow, fibrous zeolite (?) which are overgrown by zeolite.

Lithologic Unit 3 is described in detail by Kirkpatrick and Hodges (this volume).

Lithologic Unit 4 (Sample 15-5, $100 \mathrm{~cm}$ through Section 22-4) consists principally of strongly phyric basaltic pillows. Minor amounts of interpillow limestone, probably recrystallized nannofossil ooze, is present. Phenocryst phases, principally plagioclase and olivine with trace amounts of chromium-rich spinel, make up between 11 and 26 volume per cent of the samples, with plagioclase predominating over olivine. Modal data (Table 1) indicate that olivine makes up between 8 and 26 per cent (average = $14 \%$ ) of the total phenocrysts present.

Plagioclase phenocrysts in lithologic Unit 4 range from euhedral tabular to anhedral and rounded; glomerocrysts, both of plagioclase and olivine and plagioclase, are common. Melt inclusions similar to those described from Units 1 and 2 plagioclase are also common. All plagioclase phenocrysts exhibit narrow rims with normal zoning adjacent to the groundmass. Many plagioclase phenocrysts exhibit a much more complex internal zoning pattern, with irregular cores, and both reversed and oscillatory zoning. One unusual plagioclase phenocryst from Sample 16-3, $44-48 \mathrm{~cm}$ exhibits what is apparently a kink band, possibly indicative of solid-state deformation prior to inclusion in the magma. Olivine phenocrysts occur in forms ranging from euhedral through skeletal to anhedral and rounded. Weak optical zoning is present in many grains, small rounded melt inclusions are relatively common, and a small percentage of the grains exhibit well-developed kink bands. Trace amounts $(\ll 1 \%)$ of chromium-rich spinel occurs throughout the samples. The spinels, subhedral to euhedral, range from reddish brown to opaque and occur as inclusion in both plagioclase and olivine and as isolated microphenocrysts in the groundmass.

Groundmass textures within the pillows of lithologic Unit 4 range from glassy with numerous microlites of plagioclase and olivine at pillow margins through well-defined variolitic and spherulitic zones into intersertal interiors. Textural relationships are similar to those in the upper pillow unit (Kirkpatrick, this volume), and the apparent groundmass crystallization sequence is olivine ( \pm spinel), plagioclase, clinopyroxene, and titanomagnetite.

Alteration is present throughout the samples (see Honnorez et al., this volume). Palagonite is common within glassy pillow margins; calcite-phillipsite veins, similar to those described above, are relatively abundant. Olivine is commonly partly altered to iddingsite and, in more altered samples, olivine is partly replaced by calcite. Smectite is common as a replacement of residual glass and as vesicle filling within pillow interiors. Radial phillipsite is observed

TABLE 1

Modal Analyses

\begin{tabular}{|c|c|c|c|c|c|c|c|c|c|c|c|}
\hline $\begin{array}{c}\text { Sample } \\
\text { (Interval in } \mathrm{cm} \text { ) }\end{array}$ & $\begin{array}{l}16-2, \\
55-62^{a}\end{array}$ & $\begin{array}{l}16-3, \\
44-48^{a}\end{array}$ & $\begin{array}{l}16-4, \\
13-23\end{array}$ & $\begin{array}{c}16-5, \\
134-139\end{array}$ & $\begin{array}{l}17-2 \\
16-24^{\mathrm{a}}\end{array}$ & $\begin{array}{l}17-4 \\
4-13^{a}\end{array}$ & $\begin{array}{l}18-1 \\
31-36^{a}\end{array}$ & $\begin{array}{l}18-2 \\
3-9\end{array}$ & $\begin{array}{c}18-2 \\
81-89^{a}\end{array}$ & $\begin{array}{l}20-1, \\
80-90^{\text {a }}\end{array}$ & $\begin{array}{l}20-1 \\
90-101\end{array}$ \\
\hline Plagioclase Phenocrysts & 14.1 & 13.3 & 9.7 & 19.7 & 13.4 & 13.9 & 13.8 & 18.5 & 17.6 & 18.7 & 18.0 \\
\hline Olivine Phenocrysts & 3.7 & 4.6 & 0.9 & 2.4 & 1.6 & 2.7 & 2.2 & 2.0 & 3.9 & 2.6 & 3.8 \\
\hline Spinel & 0.1 & $\mathrm{tr}$ & $\operatorname{tr}$ & & $\operatorname{tr}$ & & $\mathrm{tr}$ & $\operatorname{tr}$ & 0.1 & & \\
\hline Matrix & 82.1 & 82.2 & 88.8 & 77.9 & 84.9 & 83.3 & 83.8 & 79.4 & 78.2 & 78.4 & 77.8 \\
\hline Vesicles & $\operatorname{tr}$ & $\operatorname{tr}$ & 0.7 & $\operatorname{tr}$ & 0.1 & 0.1 & 0.2 & 0.1 & 0.2 & 0.2 & 0.5 \\
\hline $\begin{array}{c}\text { Sample } \\
\text { (Interval in cm) }\end{array}$ & $\begin{array}{c}20-1, \\
104-112\end{array}$ & $\begin{array}{c}20-1, \\
120-123\end{array}$ & $\begin{array}{c}20-2, \\
136-140^{a}\end{array}$ & $\begin{array}{l}20-3, \\
3-10^{\mathrm{a}}\end{array}$ & $\begin{array}{l}20-3 \\
47-49^{a}\end{array}$ & $\begin{array}{l}20-4, \\
112-121^{\mathrm{a}}\end{array}$ & $\begin{array}{l}20-5 \\
12-20\end{array}$ & $\begin{array}{l}21-2 \\
44-47^{a}\end{array}$ & $\begin{array}{l}22-1 \\
15-17\end{array}$ & $\begin{array}{l}22-1, \\
53-61^{a}\end{array}$ & $\begin{array}{l}22-3 \\
39-45\end{array}$ \\
\hline Plagioclase Phenocrysts & 17.4 & 17.8 & 18.5 & 13.4 & 21.2 & 18.0 & 10.1 & 20.0 & 24.3 & 18.0 & 19.9 \\
\hline Olivine Phenocrysts & 2.0 & 2.8 & 4.2 & 3.3 & 3.6 & 2.4 & 1.1 & 3.2 & 2.5 & 3.4 & 2.8 \\
\hline Spinel & & & $\mathrm{tr}$ & & & & & $\mathrm{tr}$ & tr & tr & $\operatorname{tr}$ \\
\hline Matrix & 79.6 & 78.9 & 77.3 & 83.1 & 75.2 & 79.4 & 88.4 & 76.7 & 73.0 & 78.6 & 77.0 \\
\hline Vesicles & 1.0 & 0.4 & 0.1 & 0.2 & tr & 0.2 & 0.4 & $\operatorname{tr}$ & 0.2 & $\operatorname{tr}$ & 0.3 \\
\hline $\begin{array}{c}\text { Sample } \\
\text { (Interval in } \mathrm{cm} \text { ) }\end{array}$ & $\begin{array}{l}23-1, \\
92-96^{a}\end{array}$ & $\begin{array}{l}26-1, \\
3-7^{a}\end{array}$ & $\begin{array}{l}32-1 \\
21-26\end{array}$ & $\begin{array}{l}32-1, \\
49-55^{b}\end{array}$ & $\begin{array}{l}32-1, \\
49-55^{b}\end{array}$ & $\begin{array}{c}32-1, \\
100-105\end{array}$ & & & & & \\
\hline Plagioclase Phenocrysts & $\operatorname{tr}$ & 0.2 & 10.9 & 5.5 & 6.7 & 10.4 & & & & & \\
\hline $\begin{array}{l}\text { Olivine Phenocrysts } \\
\text { Spinel }\end{array}$ & 0.6 & 0.8 & $\begin{array}{l}1.4 \\
\operatorname{tr}\end{array}$ & 0.4 & 1.5 & 2.2 & & & & & \\
\hline Matrix & 99.4 & 99.0 & 87.1 & 94.1 & 91.7 & 86.8 & & & & & \\
\hline Vesicles & tr & & 0.7 & $\operatorname{tr}$ & 0.1 & 0.6 & & & & & \\
\hline
\end{tabular}

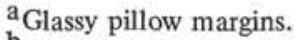

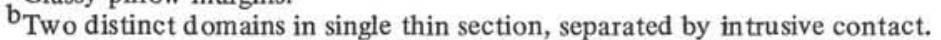


filling vesicles in several samples and two types of zeolite, unlike the usual phillipsite, were observed; length-slow, fibrous zeolite, similar to that described from Core 4 , occurs as vesicle filling in samples from Core 18; a complex zeolite intergrowth occurs as a vesicle filling in Sample 20-1, $112-119 \mathrm{~cm}$.

The bottom portion of Hole 396B (Cores 23 through 33), is characterized by erratic drilling rates and poor recovery. This bottom section, named the Clastic Zone by the shipboard scientists (Site Report, this volume), was divided into four units: (1) upper clastic breccia unit (Unit 5), (2) upper basaltic gravel unit (Unit 6), (3) plagioclase phyric basalt unit (Unit 7), and (4) lower basaltic gravel unit (Unit 8). The divisions probably result more from the vagrancies of drilling than from actual breaks in the lithology.

Unit 5, the clastic breccia unit (Cores 23 to 26,315 to $345 \mathrm{~m}$ sub-bottom), consists of fragments of sparsely phyric basaltic pillows and zeolite-cemented basaltic breccias. The basalt pieces, light brown to light green and apparently more altered than basalts from higher in the section, are principally olivine phyric, containing up to several volume per cent olivine phenocryst, and only minor amounts of plagioclase. The breccia consists of angular, coarse sand to gravel-size fragments of basaltic glass and crystalline basalt set in a matrix of radial, interlocking crystals of phillipsite. Glass fragments, invariably surrounded by rims of palagonite, predominate over crystalline basalt fragments. The breccia occurs both as discrete blocks (in one case, distinctly layered), and as fragments adhering to pillow pieces.

Unit 6, the upper basaltic gravel unit (Cores 26 to 31,345 to $386.5 \mathrm{~m}$ sub-bottom) is represented by 1 meter of basaltic gravel in Core 30. The gravel, recovered through the use of a special plastic sock in the core catcher, consists predominantly of angular fragments of crystalline basalt and of non-vesicular basaltic glass. Minor constituents include fragments of palagonite and fresh grains of olivine and plagioclase. Fragments of calcite-cemented basalt microbreccia and round to botryoidal pieces of calcite, both free and attached to basalt fragments, probably represent incipient cementation of the gravel. Large rock fragments within the gravel consist of a small, hollow basaltic pillow and two pieces of bedded basaltic sandstone. The larger of the two sandstone fragments consists of three distinct beds with well-defined grading. Grain sizes vary from greater than $3 \mathrm{~cm}$ to less than $0.1 \mathrm{~mm}$. Clastic material within the sandstone consists of fragments of both basaltic glass and crystalline basalt with numerous individual grains of plagioclase and olivine, plagioclase being much more abundant than olivine. The cement is isotopic, or nearly so, and is probably zeolitic.

Unit 7, the phyric pillow basalt unit (Core 32, 386.5 to $396 \mathrm{~m}$ sub-bottom), consists of fragments of olivine and plagioclase phyric basaltic pillows. Plagioclase contents range from less than 1 per cent to nearly 11 per cent, with up to 3 per cent olivine. Basalts in Core 32 are generally much fresher than those in Cores 23 and 24.

Unit 8, the lower basaltic gravel unit (Core 33, 396 to $405.5 \mathrm{~m}$ sub-bottom) consist of gravel very similar to that recovered in Core 30 . One sample $(32-1,49-55 \mathrm{~cm})$ contains an intrusive contact, apparently representing multiple magma pulses within a pillow.

\section{MODAL DATA}

Modal data for basalt samples for Cores 16 through 32 are presented in Table 1 and are plotted in Figure 1 in terms of plagioclase phenocrysts, olivine phenocrysts, and matrix. In Figure 1a, a plot of all modal data, the points define a line indicating that much of the modal variation may result in the redistribution of olivine and plagioclase in the proportion $1: 6$. There is a crude separation of points corresponding to chemical Sub-unit B1 (Cores 16 through 19), Sub-unit B2 (Cores 20 through 22), and Unit C (Cores 23 through 33) in Figure 1a. The separation is much better in Figure $1 \mathrm{~b}$, in which only modes of glassy pillow margins are plotted. Although the separation is not perfect, it indicates a clear difference in the phenocryst contents of the three chemical units. The much greater scatter in Figure 1a is probably a result of minor flow differentiation during pillow emplacement.

\section{CHEMISTRY}

Shipboard XRF analyses indicate that the Hole 396B samples are fairly typical low-K oceanic tholeiites with $\mathrm{Mg} / \mathrm{Mg}+$ Feror ranging from 0.57 to 0.66 (Site Report, this volume). The shipboard analyses are plotted in Figure 2 in terms of normative (CIPW) olivine, plagioclase, and pyroxene. Because of the uncertainty of the oxidation state of abyssal tholeiite magmas, the norms have been calculated with all iron in the ferrous state. In this diagram, the analyses of the sparsely phyric basalts fall along the trend identified by Shido et al. (1971) as the projection of the olivine-plagioclase cotectic and followed by most analyses of abyssal tholeiite glass (e.g., Frey et al., 1974; Bryan and Moore, 1977). The strongly phyric samples, on the other hand, all plot to the left of this trend, indicating an enrichment in plagioclase components relative to the cotectic compositions.

Electron microprobe analyses of glasses from chilled pillow margins are presented in Table 2. Each reported composition is the average of 6-point analyses $(\sim 20 \mu \mathrm{m}$ diameter, $0.015 \mu \mathrm{A}$ sample current) performed on an automated ARL EMX microprobe. An average of replicate analyses of a fused sample of USGS standard BCR-1 (Flanigan, 1973) is presented as an internal standard.

The two analyses from the upper, sparsely phyric basalts are both from chemical Sub-unit A2 and are, except for minor differences probably resulting from alteration (i.e., higher $\mathrm{K}_{2} \mathrm{O}$ in shipboard analyses), identical with the average of shipboard analyses from that unit (Table 3). Consideration of similar data for Sub-units B1 and B2 indicates differences in the direction expected in consideration of the phenocryst content of these samples. These data also indicate, at least on the basis of major element data, that the sparsely phyric basalts could be related to a magma similar, though not necessarily identical, to B1 through either gain or loss of observed phenocryst phases. Basalts of Sub-unit B2 cannot be related to basalts from Sub-unit B1 or the sparsely phyric basalts through any simple redistribution of phenocryst phases. 
F. N. HODGES
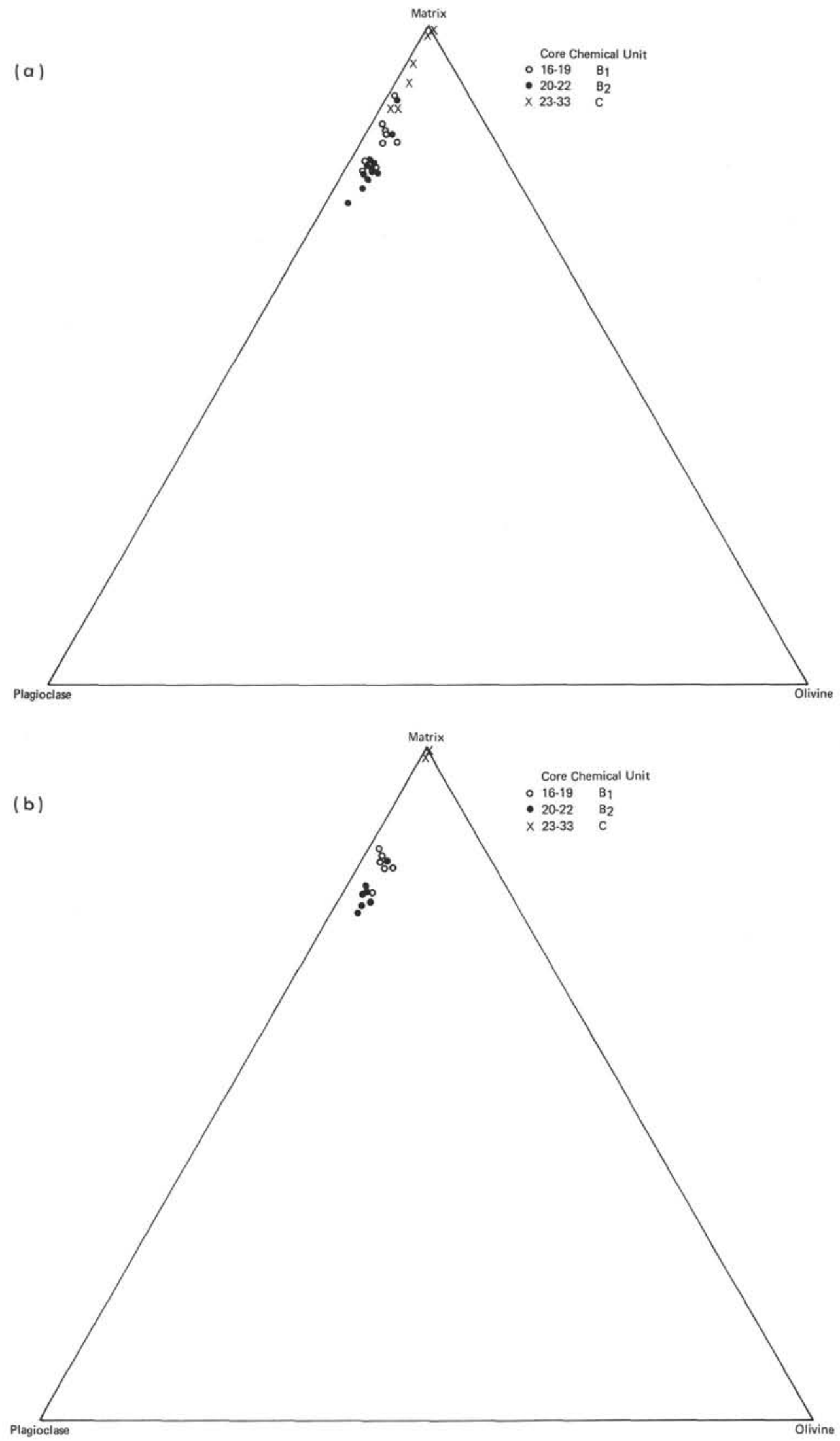

Figure 1. Modal data (a) for all samples, (b) for glassy pillow margins. 


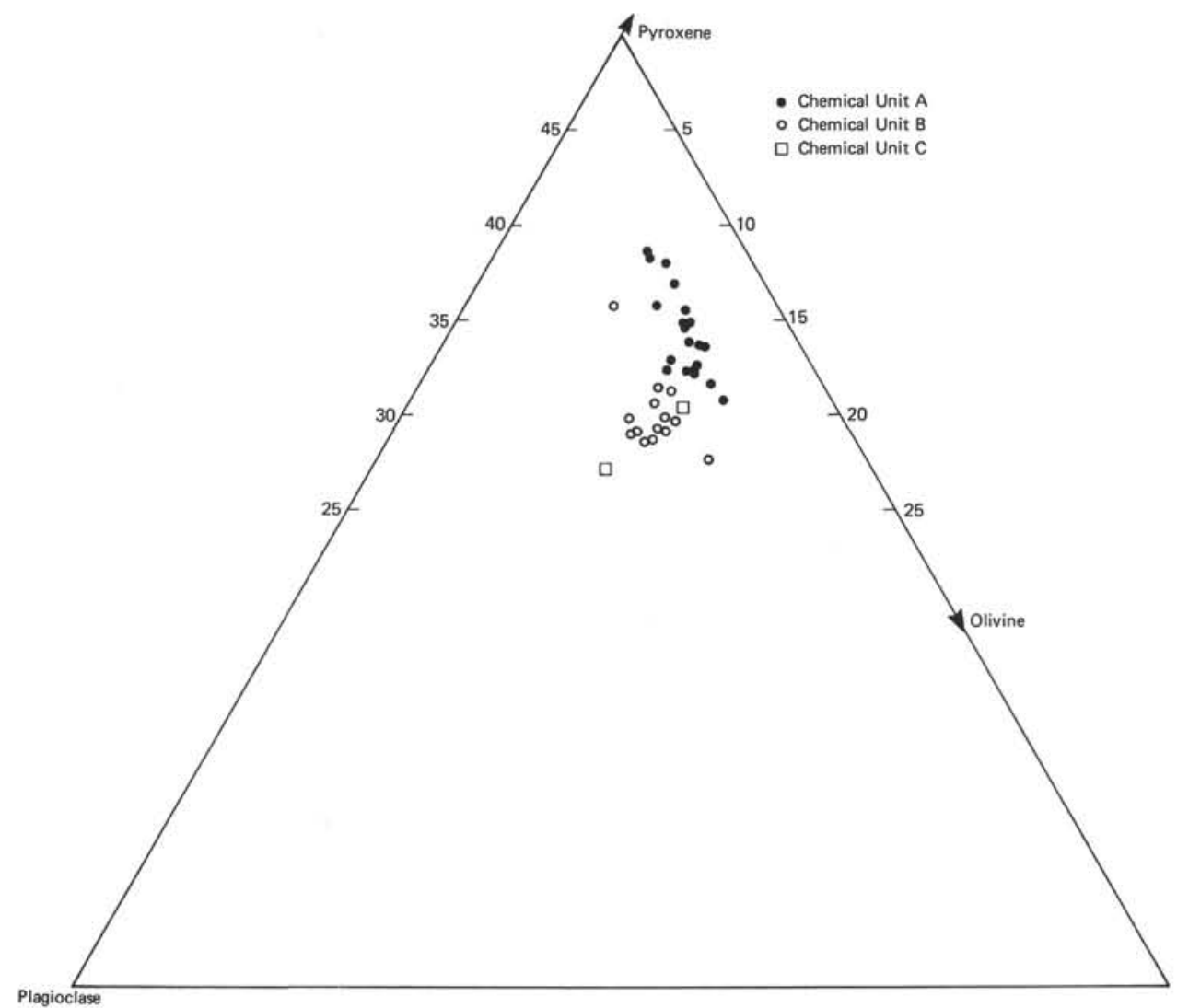

Figure 2. Normative plot (plagioclase-pyroxene-olivine) for shipboard XRF analyses Calculated with total $\mathrm{Fe}$ as $\mathrm{FeO}$.

TABLE 2

Average Electron Microprobe Analyses of Natural Glasses

\begin{tabular}{|c|c|c|c|c|c|c|c|c|c|c|}
\hline $\begin{array}{c}\text { Sample } \\
\text { (Interval in } \mathrm{cm} \text { ) }\end{array}$ & $\begin{array}{l}10-2 \\
79-88\end{array}$ & $\begin{array}{l}12-1 \\
23-34\end{array}$ & $\begin{array}{l}16-2 \\
55-62\end{array}$ & $\begin{array}{l}16-3 \\
44-48\end{array}$ & $\begin{array}{l}20-3 \\
3-10\end{array}$ & $\begin{array}{l}21-2 \\
44-47\end{array}$ & $\begin{array}{l}22-1, \\
57-61\end{array}$ & $\begin{array}{l}23-1 \\
93-96\end{array}$ & & \\
\hline Chemical Unit & A2 & A2 & B1 & B1 & B2 & B2 & B2 & C & BCR-1 ${ }^{\mathrm{a}}$ & BCR-1 ${ }^{b}$ \\
\hline $\mathrm{SiO}_{2}$ & 50.4 & 50.4 & 50.6 & 50.6 & 50.6 & 50.2 & 50.1 & 49.7 & 54.7 & 54.50 \\
\hline $\mathrm{TiO}_{2}$ & 1.58 & 1.52 & 1.49 & 1.42 & 1.24 & 1.25 & 1.15 & 1.51 & 2.31 & 2.259 \\
\hline $\mathrm{Al}_{2} \mathrm{O}_{3}$ & 15.3 & 15.3 & 15.4 & 15.3 & 15.5 & 15.6 & 15.7 & 16.0 & 13.7 & 13.61 \\
\hline $\mathrm{FeO}^{\mathrm{c}^{3}}$ & 9.6 & 9.2 & 9.3 & 9.1 & 8.6 & 8.9 & 8.8 & 9.1 & 12.2 & 12.06 \\
\hline $\mathrm{MnO}$ & 0.15 & 0.14 & 0.13 & 0.14 & 0.15 & 0.13 & 0.12 & 0.13 & 0.15 & 0.18 \\
\hline $\mathrm{MgO}$ & 8.2 & 8.0 & 7.9 & 7.8 & 8.2 & 8.3 & 8.4 & 8.0 & 3.49 & 3.46 \\
\hline $\mathrm{CaO}$ & 10.9 & 11.3 & 11.4 & 11.9 & 12.1 & 11.9 & 12.0 & 11.4 & 7.0 & 6.92 \\
\hline $\mathrm{Na}_{2} \mathrm{O}_{3}$ & 2.76 & 2.84 & 2.90 & 2.82 & 2.70 & 2.72 & 2.67 & 2.94 & 3.35 & 3.27 \\
\hline $\mathrm{K}_{2} \mathrm{O}$ & 0.09 & 0.11 & 0.09 & 0.08 & 0.06 & 0.09 & 0.10 & 0.14 & 1.66 & 1.70 \\
\hline Sum & 99.0 & 98.8 & 99.3 & 99.1 & 99.2 & 99.1 & 99.0 & 98.9 & 98.6 & \\
\hline
\end{tabular}

a This report.

blanigan et al., 1973.

${ }^{c}$ Total $\mathrm{Fe}$ as $\mathrm{FeO}$.

Norms of glass analyses, plotted on Figure 3, fall along the same trend as the sparsely phyric basalts in Figure 2 . Glasses from Sub-units A2 and B1 plot at similar positions on the diagram. The analyses from Sub-unit B2 are generally more olivine-rich and plagioclase-rich, and the glass from Core 23 (Unit C) is the most "primitive" of the glasses analyzed.

\section{DISCUSSION}

The mineralogy and crystallization sequence of the Leg 46 basalts are similar to those of oceanic tholeiite from other DSDP sites (Hodges et al., 1976) and the type of alteration present is similar to that described from other young crustal drilling sites (Bass, 1976; Scarfe and Smith, 1977; and Andrews, 1977). 
TABLE 3

Comparison of Glass Analyses With Average Chemical Compositions of Chemical Units

\begin{tabular}{l|crrrrr}
\hline & \multicolumn{2}{|c}{$\mathrm{A} 2$} & \multicolumn{2}{c}{$\mathrm{B} 1$} & \multicolumn{2}{c}{ B2 } \\
\cline { 2 - 7 } & $(1)$ & $(2)$ & \multicolumn{1}{c}{$(3)$} & \multicolumn{1}{c}{$(4)$} & \multicolumn{1}{c}{$(5)$} & $(6)$ \\
\hline $\mathrm{SiO}_{2}$ & 50.4 & 50.03 & 50.06 & 49.67 & 50.03 & 49.63 \\
$\mathrm{TiO}_{2}$ & 1.55 & 1.53 & 1.46 & 1.23 & 1.21 & 1.06 \\
$\mathrm{Al}_{2} \mathrm{O}_{3}$ & 15.3 & 15.29 & 15.4 & 16.91 & 15.6 & 17.66 \\
$\mathrm{FeO}^{\mathrm{a}}$ & 9.4 & 9.48 & 9.2 & 8.51 & 8.8 & 7.86 \\
$\mathrm{MnO}$ & 0.15 & 0.18 & 0.14 & 0.17 & 0.13 & 0.16 \\
$\mathrm{MgO}$ & 8.1 & 7.72 & 7.9 & 7.78 & 8.3 & 7.84 \\
$\mathrm{CaO}$ & 11.1 & 11.66 & 11.7 & 12.34 & 12.0 & 12.66 \\
$\mathrm{Na}_{2} \mathrm{O}$ & 2.80 & 2.65 & 2.86 & 2.45 & 2.70 & 2.43 \\
$\mathrm{~K}_{2} \mathrm{O}$ & 0.09 & 0.25 & 0.09 & 0.22 & 0.08 & 0.20 \\
\hline
\end{tabular}

Note: $(1)=$ Average of Analyses 1 and 2, Table 2; $(2)=$ Average composition, Sub-unit A2 (Site Report, this volume); (3) = Average of Analyses 3 and 4, Table 2; (4) = Average composition, Sub-unit B1 (Site Report, this volume); $(5)=$ Average of Analyses 5, 6, and 7, Table 2; $(6)=$ Average composition, Sub-unit B2 (Site Report, this volume).

${ }^{\mathrm{a}} \mathrm{Total} \mathrm{Fe}$ as $\mathrm{FeO}$.

The complex zoning patterns present in the plagioclase phenocrysts indicate a complex crystallization history prior to final incorporation into the pillows. It is uncertain whether or not these zoning patterns can result entirely from crystallization from the host magma. Xenocrystic material could be derived either from underlying crust and mantle or from subjacent magma chambers. The presence of kink bands in a small percentage of the large olivine grains and in at least one large plagioclase grain indicates that these are xenocrysts from the first source. The significance of the second source for xenocryst in abyssal tholeiites is uncertain at present.

The modal and normative data for Hole 396B basalts are consistent, with at least part of the olivine and plagioclase in the samples being xenolithic or cumulate in origin. The general trend of the modal data indicates that olivine and plagioclase are being redistributed in the ratio of 1:6; however, the cotectic boundary as generally drawn (i.e., Shido et al., 1971), would indicate crystallization of a mixture considerably richer in olivine. One possibility is that the cotectic boundary curves toward the composition of glass in Sample 23-1, 93-96 cm. If this were true, a magma similar in composition to this sample could crystallize olivine and plagioclase in approximately a 1:6 ratio. Alternately, most of the olivine and plagioclase "phenocrysts" could be derived from a subjacent magma chamber in which olivine and plagioclase were crystallizing in a ratio of 1:6.

The major element chemistry of basalts from Hole 396B is similar to that of dredge samples from the Mid-Atlantic Ridge near $22^{\circ} \mathrm{N}$ (Shido et al., 1971) and appears to be

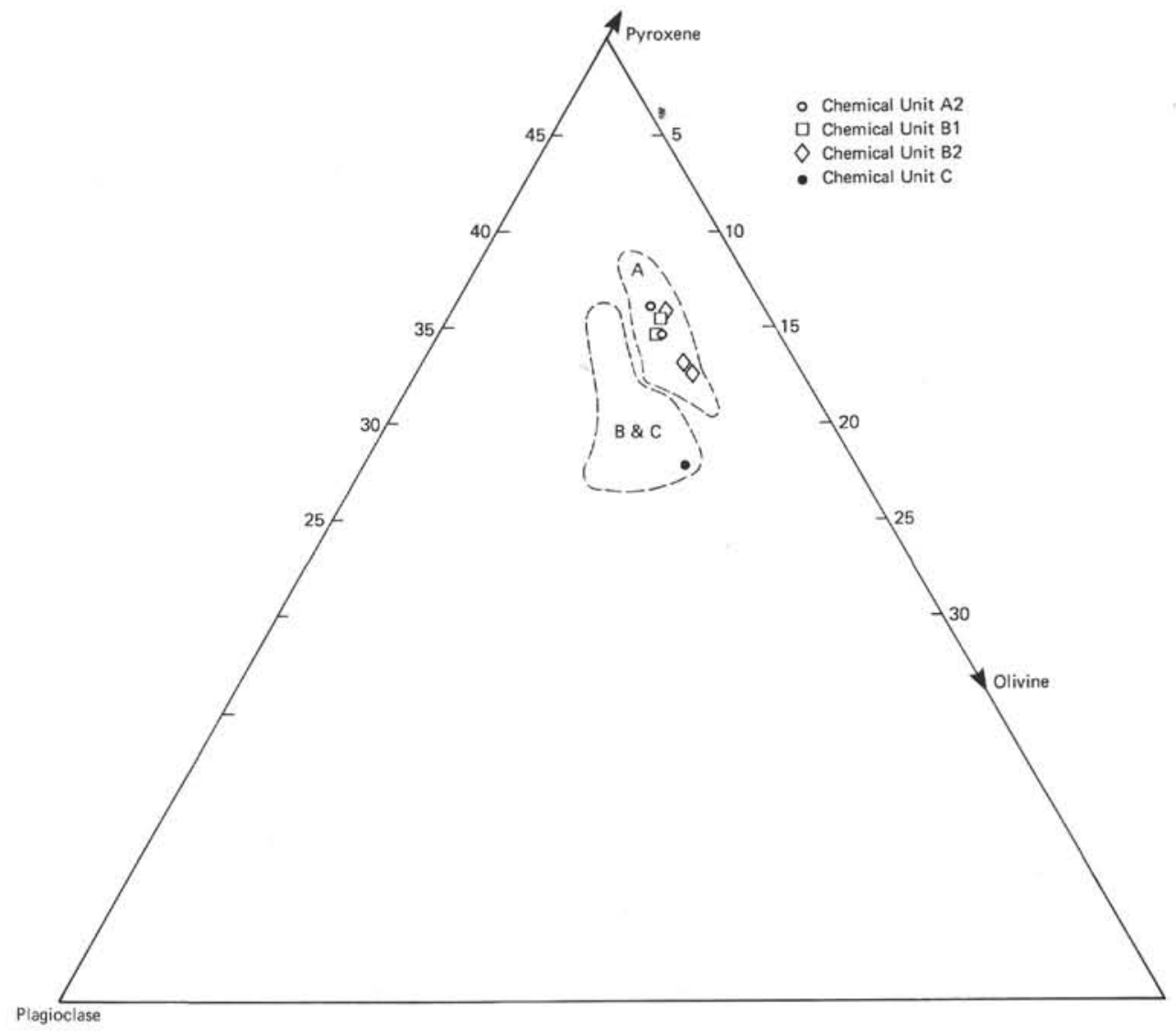

Figure 3. Normative plot (plagioclase-pyroxene-olivine) for glass analyses. $A=$ field of sparsely phyric basalts; $B$ and $C=$ field of olivine-plagioclase phyric basalts; calculated with total $\mathrm{Fe}$ as $\mathrm{FeO}$. 
systematically more evolved than the most primitive samples from FAMOUS (Bryan and Moore, 1977) and DSDP Leg 2 (Frey et al., 1974). If this represents a real regional variation pattern, and is not a result of sampling bias, it may have important implications for theories of magma genesis along the Mid-Atlantic Ridge. The occurrence of the Leg 46 samples above a thick clastic unit of basaltic composition may indicate that the sampled basalts represent more evolved magma erupted along the margin of the Mid-Atlantic Ridge rift.

The basaltic gravel and its associated breccias and sandstones are somewhat unusual, at least in their recovery; however, similar formations may be responsible for drilling difficulties at other young crustal drilling sites. That the gravel is real and not an artifact of drilling (drilling breccia) is indicated by several lines of evidence: the presence of similar gravel in cemented breccia in Core 23; the presence of basaltic sandstones within the gravel unit; the very poor core recovery in the interval below Core 23; the Schlumberger geophysical log data which is consistent with the presence of a single 90 -meter-thick gravel layer in the lower part of the hole (Kirkpatrick, this volume); and lastly, the conviction of the drillers, based upon their prior experience, that they were drilling through gravel.

The origin of the basaltic gravel presents an interesting problem. The ocean depths involved and the nonvesicularity of the glass fragments argue strongly against a pyroclastic or explosive origin for the fragments. An origin through the brecciation of quench crust on moving flows (hyaloclastite) seems ruled out by the great thickness indicated for the clastic material, the abundance of crystalline basalt fragments, and the indication (calcite veinlets) that at least some of the material was altered prior to brecciation. In light of all the data, it seems most likely that the lower 90 meters of the hole is part of a large tectonic debris or talus cone derived from pre-existing pillow basalts and that the intervals of larger pillow fragments, such as those in Core 32 , simply represent layers of coarser debris within the deposit. The most probable location for the development of a deposit of this type is along the scarp of an active fault, an origin that appears particularly likely at Site 396B which is located in a relatively small, fault-bounded sediment pond (Site Report, this volume).

Another interesting problem is the relative freshness of the clastic material, given its much greater porosity and permeability. Oxygen isotope data (Muehlenbachs and Hodges, this volume) indicate that material from below Core 23 has exchanged less oxygen with sea water than material in the overlying pillow units. In addition, in situ heat-flow measurements (Erickson, this volume) indicate that the bottom portion of the section may have been sealed off from direct sea water circulation prior to drilling of the hole. On the basis of these data, it seems probable that the zeolite-cemented breccias in Core 23 represent an impermeable hydrologic cap, blocking sea water circulation into the gravel. It is unclear how a cap of this type might form; however, one possibility is that the hydrologic parameters of the gravels and the overlying pillow sequence are different enough that they initially evolved their own independent circulation or convection systems. In this case, the brines of the two circulation systems would mix at the basalt-gravel interface and reaction between the two brines, probably differing slightly in chemistry, could lead to the cementation of the upper portion of the gravel.

\section{REFERENCES}

Andrews, A.J., 1977. Low temperature fluid alteration of oceanic layer 2 basalt, DSDP Leg 37, Canadian Journal of Earth Sciences, v. 14, p. 911-926.

Bass, M.N., 1976. Secondary minerals in oceanic basalts, Annual Report of the Director Department of Terrestrial Magnetism, 1974-1975, Washington, p. 234-240.

Bryan, W.B.. and Moore, J.G., 1977. Compositional variations of young basalts in the Mid-Atlantic Ridge rift valley near $36^{\circ} 49^{\prime} \mathrm{N}$ Geological Society of America Bulletin, v. 88, p. $556-570$.

Flanagan, F.J., 1973. 1972 values for international geochemical reference samples, Cosmochimica et Geochimica Acta, v. 37, p. $1189-1200$.

Frey, F.A., Bryan, W.B., and Thompson, G., 1974. Atlantic Ocean floor: Geochemistry and petrology of basalts from Legs 2 and 3 of the Deep-Sea Drilling Project, Journal of Geophysical Research, v. 79, p. 5507-5527.

Hodges, F.N., Papike, J.J., and Bench, A.E., 1976. Mineral chemistry of deep sea basalts, EOS, v. 57 , p. 406.

Scharfe, C.M., and Smith, D.G.W., 1977. Secondary minerals in some basaltic rocks from DSDP Leg 37, Canadian Journal of Earth Sciences, v. 14, p. 903-910.

Shido, F., Miyashiro, A., and Ewing, M., 1971. Crystallization of abyssal tholeiites, Contributions to Mineralogy and Petrology, v. 31 , p. $251-266$. 